\title{
Physical and mechanical properties of coconut palm (Cocos nucifera) stem
}

\author{
M. N. $\operatorname{Rana}^{1}$, A. K. Das ${ }^{1,2 *}$ and M. Ashaduzzaman ${ }^{3}$ \\ ${ }^{1,3}$ Forestry and Wood Technology Discipline, Khulna University, Khulna-9208, Bangladesh. \\ ${ }^{2}$ Pulp and Paper Technology, Asian Institute of Technology, Thailand.
}

\begin{abstract}
A study was conducted on coconut palm (Cocos nucifera) stem of Khulna region in Bangladesh. Important physical and mechanical properties were studied for 40-year-old tree. The test was done at different height positions (i.e., top, middle and bottom) and lateral positions (i.e., core and periphery). The average air dry and oven dry density of coconut stem was 400 and $460 \mathrm{~kg} / \mathrm{m}^{3}$, respectively. The MOE and MOR values for air dry and oven dry conditions were 2374 and $2633 \mathrm{~N} / \mathrm{mm}^{2}$ and 27.30 and $30.44 \mathrm{~N} / \mathrm{mm}^{2}$. The compression strength in parallel to grain and perpendicular to grain for air dry and oven dry conditions were 12.41 and $12.85 \mathrm{~N} / \mathrm{mm}^{2}$ and $9.28 \mathrm{and} 9.64 \mathrm{~N} / \mathrm{mm}^{2}$, respectively. There is a possibility to use the stem of coconut palm for different structural purposes.
\end{abstract}

Key words: Physical properties; Mechanical properties; Cocos nucifera

\section{Introduction}

The Coconut palm (Cocos nucifera) is a member of the Family Arecaceae (palm family). It is the only species in the genus Cocos, and is a large palm, growing to $30 \mathrm{~m}$ tall and diameter up to $60-70 \mathrm{~cm}$ with pinnate leaves 4-6 m long, pinnae 60-90 cm long; old leaves break away cleanly leaving the trunk smooth. The term coconut refers to the fruit of the coconut palm. The local name of coconut tree in Bangladesh is narikel, dab. The coconut palm thrives on sandy soils and is highly tolerant of salinity. It prefers areas with abundant sunlight and regular rainfall (1,500 to 2,500 mm annually), which makes colonizing shorelines of the tropics relatively straightforward. Coconut trees also need high humidity (70-80\% and above) for optimum growth, which is why they are rarely seen in areas with low humidity, like the Mediterranean, even where temperatures are high enough (regularly above $24^{\circ} \mathrm{C}$ ) (Wikipedia, 2008). The available evidences in respect of origin of coconut show that the home of coconut might have been somewhere in South-East Asia, most probably in Malaysia or Indonesia. It is distributed in Philippines, Indonesia, India, Malaysia, Sri Lanka, Thailand, Vietnam, Federated States of Micronesia, Fiji, Papua New Guinea, Western Samoa, Vanuatu, Solomon Islands. One of primary uses of coconut timber is for building construction. Coconut timber is suitable for housing components like trusses, purlins, walls, joists, doors, window frames and jalousies (Arancon, 1997).

Physical properties are very important consideration in selecting wood for numerous uses, such as furniture and cabinet making, construction of frame, bridge, building structures, sporting goods, measuring instruments, musical instruments, particle boards, decorative surfaces, insulating media etc. (Anon, 1970). Mechanical properties of wood indicate the ability of wood to resist various types of external forces, static or dynamic, which may act on it. Mechanical properties are very much important in case of constructional and structural purposes timber. The properties not only vary with species, with reference to the nature of their fiber structure but also with the moisture content, temperature and defects of wood. Sometimes the properties vary with reference to the varying conditions of growth, methods of testing and preservation and preservations methods applied (Anon, 1970).

Coconut palm is often described as a tree of life and is one of the most important crops in the tropics (Arancon, 1997). People use its timber for different structural purposes (Arancon, 1997). There are many coconut plantations and people cut the coconut trees at a certain age in Bangladesh. The information of properties shows the proper utilization of coconut timber. There are few studies on the properties of coconut timber (Anon, 2014). Therefore, this study was undertaken to find out the physical and mechanical properties of the wood to assess its use it in the furniture industry as well as structural purposes.

\section{Materials and methods}

Coconut trees were collected from Tutpara, Khulna City, Khulna (22 48' 0" N and 89 33' 0" E), Bangladesh. Sampled 
trees were 40-years-old, fairly straight and free from defects. The height of the trees was 1150 to $1250 \mathrm{~cm}$ and diameter was 27.6 to $30.8 \mathrm{~cm}$.

The boles were sawed according to standard sawing diagram with $91.4 \mathrm{~cm}$ band saw. The inner zone was selected up to 13 $\mathrm{cm}$ from the pith and the outer zone was after $13 \mathrm{~cm}$ to 14.6 $\mathrm{cm}$ for the tree with diameter of $27.6 \mathrm{~cm}$. On the other hand, the inner zone was selected from the pith up to $15 \mathrm{~cm}$ and outer zone was selected after $15 \mathrm{~cm}$ to $15.8 \mathrm{~cm}$ for the tree of $30.8 \mathrm{~cm}$ diameter.

The sample size for doing test of physical properties was 5.5 $\mathrm{cm} \times 5.5 \mathrm{~cm} \times 2.5 \mathrm{~cm}$. The specimen for compression strength was in the form of $2 \mathrm{~cm} \times 4 \mathrm{~cm} \times 8 \mathrm{~cm}$ for perpendicular and $3 \mathrm{~cm} \times 3 \mathrm{~cm} \times 8 \mathrm{~cm}$ for parallel to the grain analyses. For the test of MOR and MOE, the sample size was $2.5 \mathrm{~cm} \times 5.5 \mathrm{~cm} \times 35 \mathrm{~cm}$. Samples were taken from both inner and outer zones of the stem in all height positions of the stem, i.e., top, middle and bottom.

Mechanical properties were carried out by using Hydraulic Universal Testing Machine (UTM), Model No.WE-100, made in Time Group Inc. in Mechanical Lab of Khulna University of Engineering and Technology, Khulna.

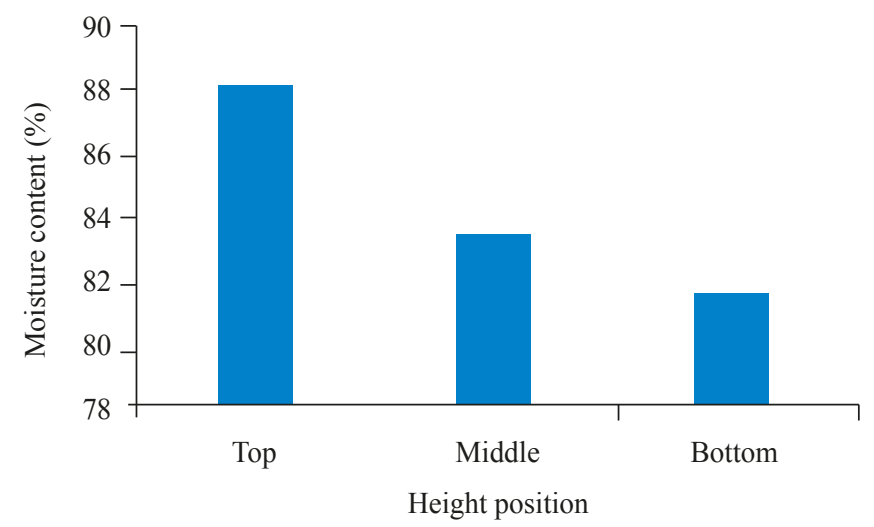

Fig. 1. Moisture content at different height positions

\section{Results and discussion}

The moisture content was different at different height positions (Fig. 1). The highest moisture content was for top portion and bottom portion showed the lowest moisture content (Fig. 1). In the study, the average green moisture content of coconut stem ranged 81.52 to $88.07 \%$ (Table 1). The highest moisture content was $88.28 \%$ in the periphery portion of the top and the lowest amount was $79.87 \%$ in the core portion of the bottom (Table 1). There was significant difference among different height positions for moisture content, but there was no significant difference for moisture content between periphery and core portion (Table 3 ).

The tangential shrinkage and the longitudinal shrinkage were different at different height positions (Fig. 2). The volumetric shrinkage was also different at different height positions (Fig. 3 ). The highest shrinkage value was found for the top portion in all cases (Fig. 2 and Fig. 3). The average shrinkage at tangential direction was 5.25 to $5.81 \%$, radial 5.07 to $5.42 \%$ and longitudinal 0.88 to $1.20 \%$. Table 1 shows that the average volumetric shrinkage was $11.8 \%$. According to the reports (Koubaa and Smith, 1959, Karki 2001, Pliura et al. 2005 and Kord et al. 2010) higher shrinkage is found for higher density wood. In this study, there was insignificant difference at tangential, radial, longitudinal and volumetric shrinkage at different height positions (Table 3). There was also insignificant difference for shrinkage between periphery and core portion (Table 3 ).

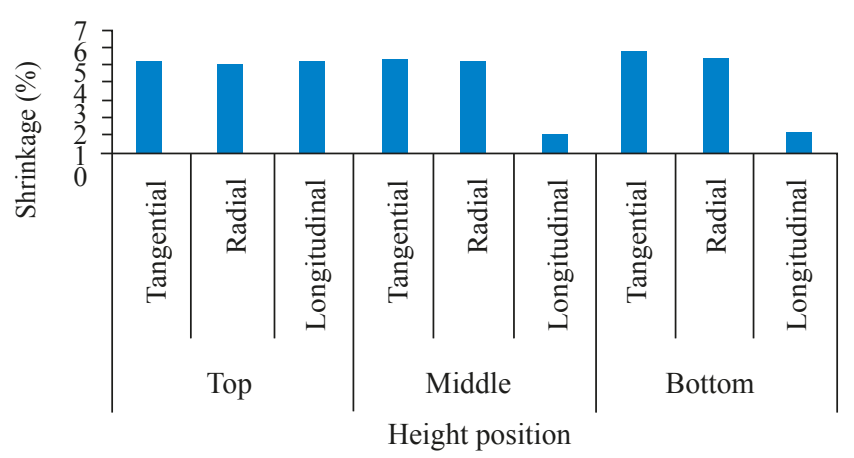

Fig. 2. Shrinkage at different height and lateral positions

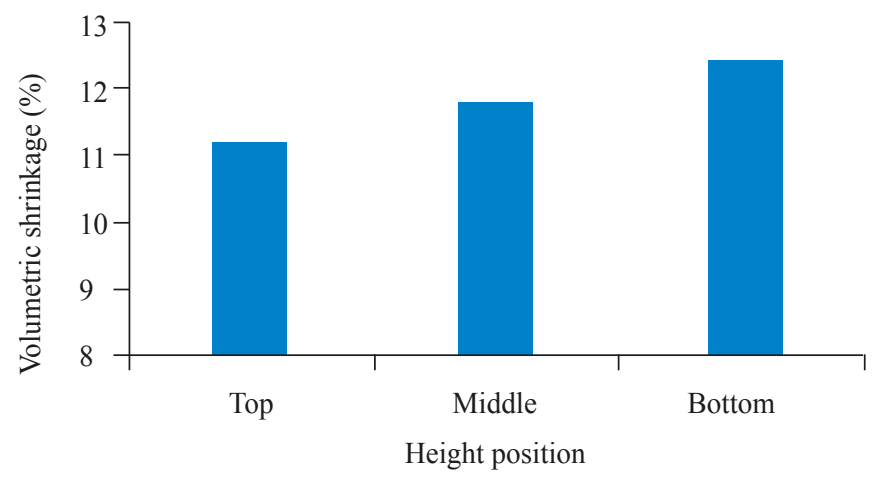

Fig. 3. Volumetric shrinkage at different height positions 
Table I. Moisture content (\%) and shrinkage (\%) Cocos nucifera stem at different height and lateral positions

\begin{tabular}{|c|c|c|c|c|c|c|}
\hline \multirow{2}{*}{$\begin{array}{l}\text { Height } \\
\text { position }\end{array}$} & \multirow{2}{*}{$\begin{array}{l}\text { Lateral } \\
\text { position }\end{array}$} & \multirow{2}{*}{$\begin{array}{c}\text { Moisture } \\
\text { content }(\%)\end{array}$} & \multicolumn{4}{|c|}{ Shrinkage (\%) } \\
\hline & & & Tangential & Radial & Longitudinal & Volumetric \\
\hline \multirow{3}{*}{ Top } & Periphery & 88.28 & 5.23 & 4.90 & 0.78 & 11.2 \\
\hline & Core & 87.85 & 5.26 & 5.23 & 0.98 & \\
\hline & Average & $88.07(3.84)$ & $5.25(0.02)$ & $5.07(0.32)$ & $0.88(0.22)$ & \\
\hline \multirow{3}{*}{ Middle } & Periphery & 83.60 & 5.35 & 5.14 & 0.79 & \\
\hline & Core & 83.09 & 5.50 & 5.36 & 1.43 & 11.8 \\
\hline & Average & $83.35(3.20)$ & $5.43(0.11)$ & $5.25(0.17)$ & $1.11(0.47)$ & \\
\hline \multirow[b]{2}{*}{ Bottom } & Periphery & 83.17 & 5.43 & 5.32 & 0.86 & \\
\hline & $\begin{array}{c}\text { Core } \\
\text { Average }\end{array}$ & $\begin{array}{c}79.87 \\
81.52(4.24)\end{array}$ & $\begin{array}{c}6.18 \\
5.81(0.53)\end{array}$ & $\begin{array}{c}5.52 \\
5.42(0.23)\end{array}$ & $\begin{array}{c}1.54 \\
1.20(0.41)\end{array}$ & 12.4 \\
\hline Average & & 84.31 & 84.31 & 5.46 & 5.25 & 11.8 \\
\hline
\end{tabular}

Note: Values in the parenthesis show standard deviation

In air dry condition, the average density was 370 to $430 \mathrm{~kg} / \mathrm{m}^{3}$ and it was 400 to $520 \mathrm{~kg} / \mathrm{m}^{3}$ for dry condition (Table 2). The average density of oven dry condition for top, middle and bottom position was higher than that of air dry condition (Table 2). The density of core portion of top, middle and bottom position was higher than that of periphery portion for both air dry and oven dry condition (Table 2). Significant difference was found for both air dry and oven dry density among different height positions i.e., top, middle but insignificant difference was found between periphery and core portion (Table 3).

\section{Table II. Air dry and oven dry density of Cocos nucifera at different height and lateral positions}

\begin{tabular}{|c|c|c|c|}
\hline \multirow{2}{*}{ Position } & \multirow{2}{*}{ Lateral position } & \multicolumn{2}{|c|}{ Density $\left(\mathrm{kg} / \mathrm{m}^{3}\right)$} \\
\hline & & Air dry & Oven Dry \\
\hline \multirow{3}{*}{ Top } & Periphery & 340 & 390 \\
\hline & Core & 390 & 410 \\
\hline & Average & $370(35.35)$ & $400(14.14)$ \\
\hline \multirow{3}{*}{ Middle } & Periphery & 400 & 450 \\
\hline & Core & 410 & 480 \\
\hline & Average & $410(7.07)$ & $470(21.21)$ \\
\hline \multirow{3}{*}{ Bottom } & Periphery & 410 & 490 \\
\hline & Core & 440 & 540 \\
\hline & Average & $430(21.21)$ & $520(35.36)$ \\
\hline \multicolumn{2}{|c|}{ Average } & 400 & 460 \\
\hline
\end{tabular}


Table III. Summery for statistical analysis of physical properties

\begin{tabular}{cccccccc}
\hline $\begin{array}{c}\text { Source of } \\
\text { variation }\end{array}$ & MC & Tangential & Radial & Longitudinal & Volumetric & AD & OD \\
\hline Height position & $*$ & $\mathrm{~ns}$ & $\mathrm{~ns}$ & $\mathrm{~ns}$ & $\mathrm{~ns}$ & $*$ & $*$ \\
Lateral position & $\mathrm{ns}$ & $\mathrm{ns}$ & $\mathrm{ns}$ & $\mathrm{ns}$ & $\mathrm{ns}$ & $\mathrm{ns}$ & $\mathrm{ns}$ \\
\hline
\end{tabular}

$*=$ Significant at $\mathrm{P}<0.05$ and $\mathrm{ns}=$ not significant

The oven dry MOE and MOR was higher than that of air dry MOE and MOR at different height positions (Fig. 4 and Fig. 5). The average MOE and MOR of bottom portion showed the highest value (Fig. 4 and Fig. 5). The MOE in air dry condition was 2310 to $2620 \mathrm{~N} / \mathrm{mm}^{2}$ and MOR 27.06 to 30.67 $\mathrm{N} / \mathrm{mm}^{2}$ (Table 4). On the other hand, the MOE in oven dry condition was 2533 to $2931 \mathrm{~N} / \mathrm{mm}^{2}$ and MOR 29.93 to 34.49 $\mathrm{N} / \mathrm{mm}^{2}$ (Table 4). The MOE and MOR values were the highest at the bottom of core portion and the lowest at the top height positions in air dry and oven dry conditions (Table 6). The difference in MOE and MOR in both the conditions was insignificant between periphery and core portions (Table 6). Core portion of bottom was better than other portions.

The average values in parallel to grain and perpendicular to grain in oven dry condition were higher than those in air dry condition at different height positions (Fig. 6 and Fig. 7). The bottom portion of parallel to grain and perpendicular to grain showed the best performance (Fig. 6 and Fig. 7). The average

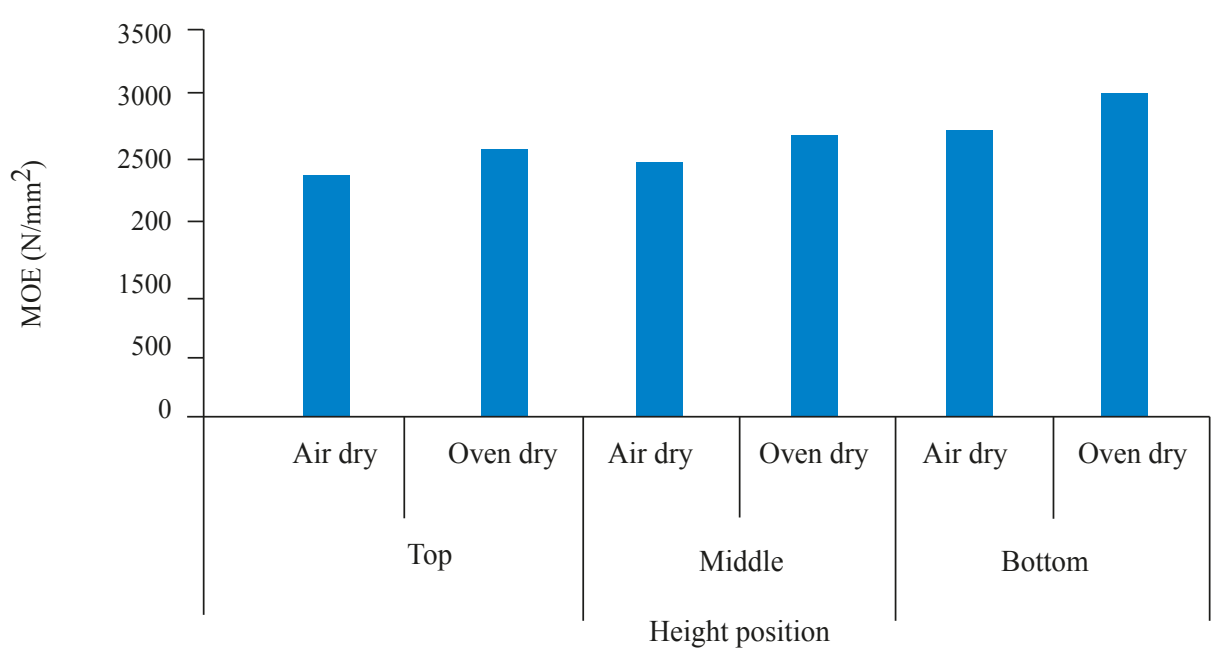

Fig. 4. Air dry and oven dry MOE at different height positions

of periphery portion in both air dry and oven dry condition (Table 4). In previous study, it was observed that MOR and MOE increased with increasing density (Haygreen and Bowyer, 1989; Desch and Dinwoodie, 1996). It has been found that lower moisture content enhanced MOR and MOE of wood (Gerhards 1982 and Matan and Kyokong 2003). MOE and MOR were significantly different among different air dry compression strength parallel to grain was 12.41 to $13.38 \mathrm{~N} / \mathrm{mm}^{2}$ and 11.26 to $7.39 \mathrm{~N} / \mathrm{mm}^{2}$ for perpendicular to grain (Table 5). In case of oven dry condition, the compression strength parallel to grain was 14.14 to 11.63 $\mathrm{N} / \mathrm{mm}^{2}$ and perpendicular to grain 11.60 to $7.88 \mathrm{~N} / \mathrm{mm}^{2}$ (Table 5). The value in perpendicular to grain was higher than that of parallel to grain in the both conditions (Table 5). In the study, compression strength parallel to grain and 


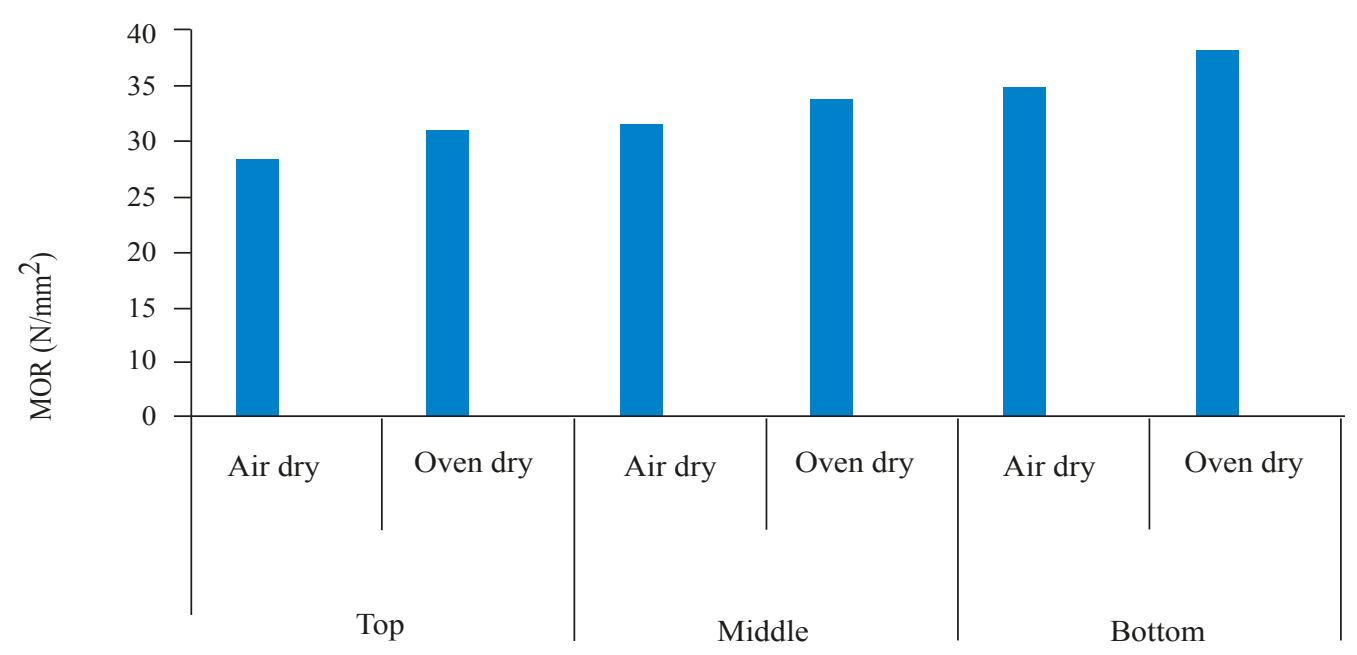

Height position

Fig. 5. Air dry and oven dry MOR at different height positions

Table IV. MOR and MOE of Cocos nucifera stem at different height and lateral positions

\begin{tabular}{|c|c|c|c|c|c|}
\hline \multirow{2}{*}{$\begin{array}{l}\text { Height } \\
\text { position }\end{array}$} & \multirow{2}{*}{$\begin{array}{l}\text { Lateral } \\
\text { position }\end{array}$} & \multicolumn{2}{|c|}{ Air d ry condition } & \multicolumn{2}{|c|}{ Ov en dry c ondition } \\
\hline & & $\begin{array}{c}\mathrm{MOE} \\
\left(\mathrm{N} / \mathrm{mm}^{2}\right)\end{array}$ & $\begin{array}{c}\mathrm{MOR} \\
\left(\mathrm{N} / \mathrm{mm}^{2}\right)\end{array}$ & $\begin{array}{c}\mathrm{MOE} \\
\left(\mathrm{N} / \mathrm{mm}^{2}\right)\end{array}$ & $\begin{array}{c}\text { MOR } \\
\left(\mathrm{N} / \mathrm{mm}^{2}\right)\end{array}$ \\
\hline \multirow{3}{*}{ Top } & Periphery & 2188 & 24.03 & 2416 & 26.57 \\
\hline & Core & 2195 & 24.31 & 2452 & 27.25 \\
\hline & Average & $2191(65.30)$ & 24.17 (1.09) & $2434(59.07)$ & $26.91 \quad(0.95)$ \\
\hline \multirow{3}{*}{ Middle } & Periphery & 2303 & 26.31 & 2529 & 29.89 \\
\hline & Core & 2316 & 27.81 & 2537 & 29.97 \\
\hline & Average & $2310(100.94)$ & $27.06(1.75)$ & $2533(51.18)$ & $29.93(0.35)$ \\
\hline \multirow{3}{*}{ Bottom } & Periphery & 2552 & 30.48 & 2911 & 34.48 \\
\hline & Core & 2687 & 30.85 & 2951 & 34.50 \\
\hline & Average & $2620(91.53)$ & $30.67(1.41)$ & 2931 (55.94) & $34.49(1.14)$ \\
\hline \multicolumn{2}{|c|}{ Average } & 2374 & 27.30 & 2633 & 30.44 \\
\hline
\end{tabular}

Note: Values in the parenthesis show standard deviation 


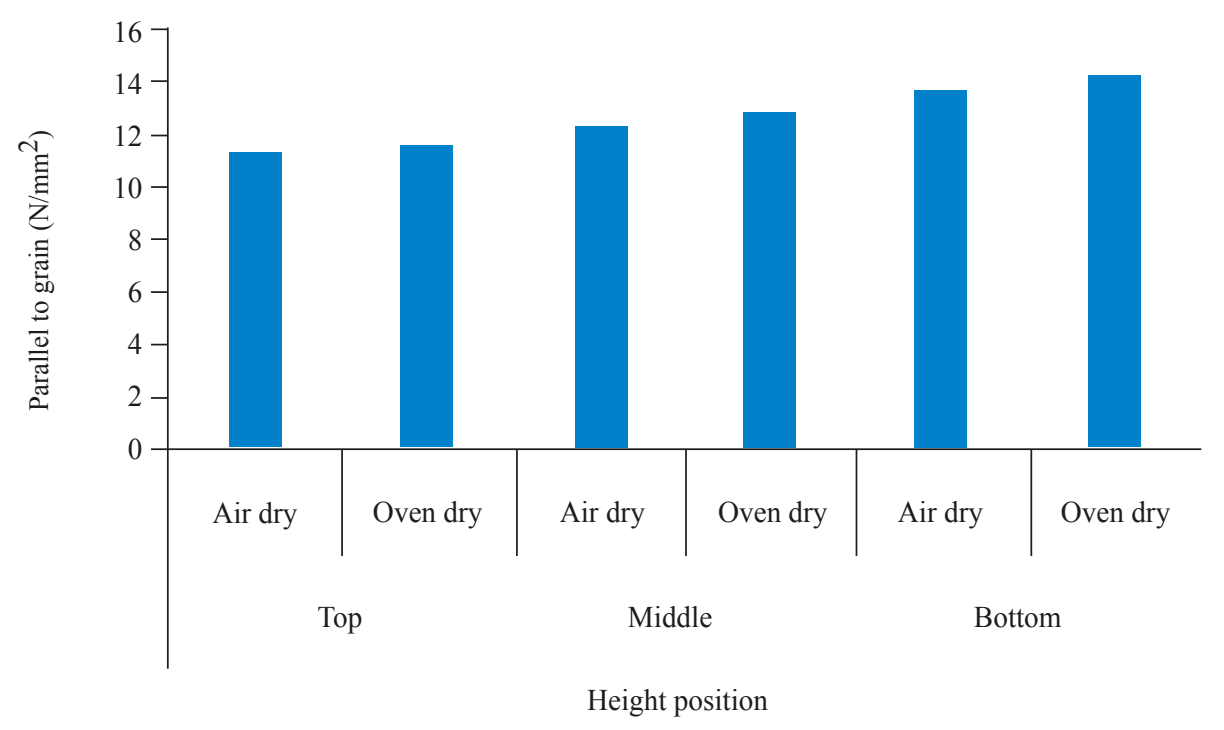

Fig. 6. Air dry and oven dry parallel to grain at different height positions

Table V. Compression strength of Cocos nucifera stem at different height and lateral positions

\begin{tabular}{|c|c|c|c|c|c|}
\hline \multirow{2}{*}{$\begin{array}{l}\text { Height } \\
\text { position }\end{array}$} & \multirow{2}{*}{$\begin{array}{l}\text { Lateral } \\
\text { position }\end{array}$} & \multicolumn{2}{|c|}{ Air dry condition } & \multicolumn{2}{|c|}{ Oven dry condition } \\
\hline & & $\begin{array}{l}\text { Parallel to grain } \\
\qquad\left(\mathrm{N} / \mathrm{mm}^{2}\right)\end{array}$ & $\begin{array}{c}\text { Perpendicular } \\
\text { to grain } \\
\left(\mathrm{N} / \mathrm{mm}^{2}\right)\end{array}$ & $\begin{array}{c}\text { Parallel to } \\
\left.\text { grain(N/mm }{ }^{2}\right)\end{array}$ & $\begin{array}{c}\text { Perpendicular } \\
\text { to grain } \\
\left(\mathrm{N} / \mathrm{mm}^{2}\right)\end{array}$ \\
\hline \multirow{3}{*}{ Top } & Periphery & 10.34 & 6.02 & 11.06 & 7.16 \\
\hline & Core & 12.22 & 7.13 & 12.05 & 8.6 \\
\hline & Average & $11.28(1.33)$ & $6.58(0.78)$ & $11.56(0.70)$ & $7.88(0.86)$ \\
\hline \multirow{3}{*}{ Middle } & Periphery & 10.56 & 8.38 & 11.20 & 8.37 \\
\hline & Core & 14.07 & 11.24 & 14.51 & 10.51 \\
\hline & Average & $12.32(2.48)$ & $9.81(2.02)$ & $12.86(2.34)$ & $9.44 \quad(1.32)$ \\
\hline \multirow{3}{*}{ Bottom } & Periphery & 10.87 & 8.76 & 12.38 & 9.75 \\
\hline & Core & 16.41 & 14.14 & 15.89 & 13.44 \\
\hline & Average & $13.64(3.92)$ & $11.45(3.80)$ & $14.14 \quad(2.09)$ & $11.60 \quad(2.22)$ \\
\hline \multicolumn{2}{|c|}{ Average } & 12.41 & 9.28 & 12.85 & 9.64 \\
\hline
\end{tabular}




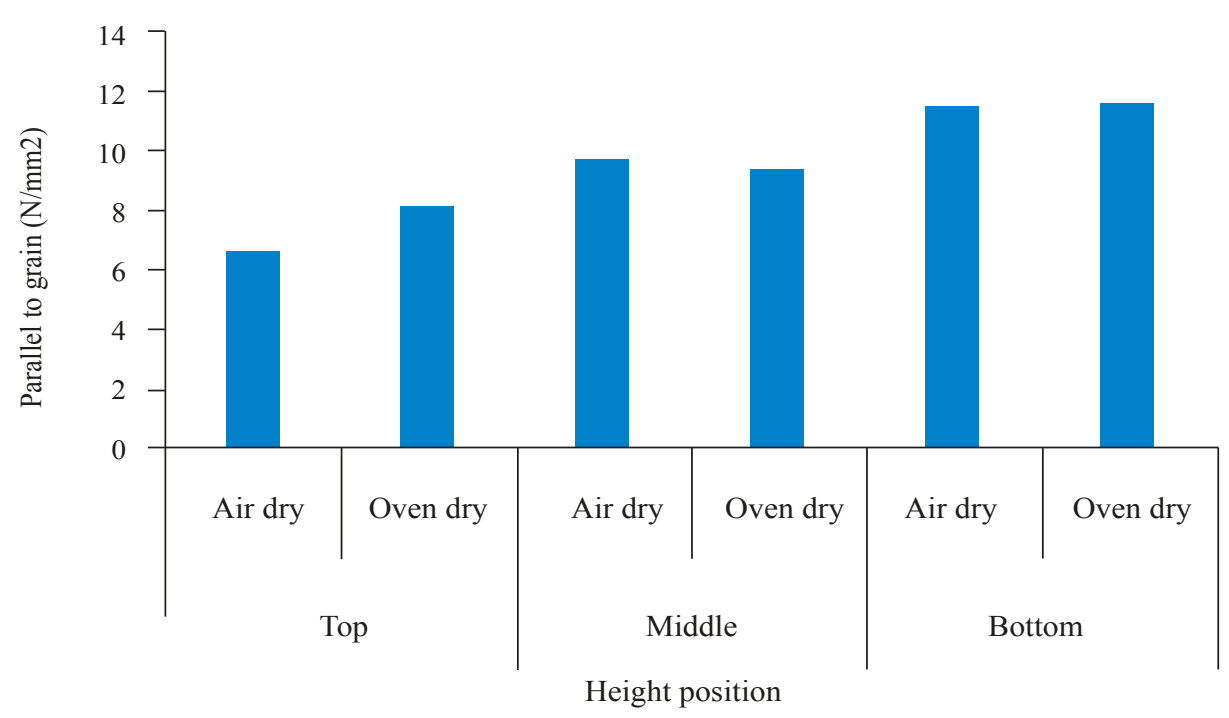

Fig. 7. Air dry and oven dry perpendicular to grain at different height positions

Table VI. Summery for statistical analysis of mechanical properties

\begin{tabular}{|c|c|c|c|c|c|c|c|c|}
\hline \multirow{3}{*}{$\begin{array}{l}\text { Source of } \\
\text { variation }\end{array}$} & \multicolumn{2}{|c|}{ MOE } & \multicolumn{2}{|c|}{ MOR } & & \multicolumn{3}{|c|}{ Compression strength } \\
\hline & \multirow[b]{2}{*}{$\mathrm{AD}$} & \multirow[b]{2}{*}{ OD } & \multirow[b]{2}{*}{$\mathrm{AD}$} & \multirow[b]{2}{*}{ OD } & \multicolumn{2}{|c|}{ Parallel to grain } & \multicolumn{2}{|c|}{ Perpendicular to grain } \\
\hline & & & & & $\mathrm{AD}$ & OD & $\mathrm{AD}$ & OD \\
\hline Height position & * & $*$ & $*$ & $*$ & $*$ & $*$ & $*$ & $*$ \\
\hline Lateral $p$ osition & ns & ns & ns & $\mathrm{ns}$ & $*$ & $*$ & $*$ & $*$ \\
\hline
\end{tabular}

$*=$ Significant at $\mathrm{P}<0.05$ and $\mathrm{ns}=$ not significant

perpendicular to grain were significantly different at different height positions and between periphery and core portion in both the conditions (Table 6).

\section{Conclusion}

The density of the coconut tree was 400 to $460 \mathrm{~kg} / \mathrm{m}^{3}$. The MOR and MOE of core portion were higher at different height positions. The timber can be used for structural purposes considering the mechanical properties. Further study is necessary to get information regarding the effect of site variation on the properties of coconut stem.

\section{Reference}

Anon. (1970). Indian Forest Utilization, Volume 1, Forest Research Institute and Colleges, Dhera Dun, India, pp 179-185.
Anon. (2014) Coconut palm stem processing: technical handbook. Retrieved from h t t p : / / w w w. fa o.org/d o c r e p / 009 / ag335e/AG335E02.htm.

Arancon R. N. (1997). Asia Pacific Forestry Sector Outlook: Focus on Coconut Wood. Working Paper No. APFSOS/WP/23, Forestry Policy and Planning Division, Rome \& Regional Office for Asia and the Pacific, Bangkok, p 35.

Desch H. E. and Dinwoodie J. M. (1996). Timber Structure, Properties, Conversion and Use. $7^{\text {th }}$ Ed.(Macmillan press Limited. London), P 306.

Gerhards C. C. (1982). Effect of Moisture Content and Temperature on The Mechanical Properties of Wood: 
An Analysis Of Immediate Effects Wood and Fiber, 14(1):4-36.

Haygreen J. G. and Bowyer J. L. (1989). Forest Products and Wood Science, Iowa State University Press, USA.

Karki T. (2001). Variation of wood density and shrinkage in European aspen (Populus tremula). Holz J , 59: 79-84.

Kord B., Kialashaki A. and Kord B. (2010). The within-tree variation in wood density and shrinkage, and their relationship in Populus euramericana. Turk J Agric For, 34: 121-126.

Koubaa R. W. and Smith J. H. G. (1959). The effect of some genetic and environmental factors on wood quality in poplar. Pulp \& Paper J, 59: 37-38.

Matan N. and Kyokong B. (2003). Effect of moisture content on some physical and mechanical properties of juvenile rubberwood (Hevea brasiliensis Muell. Arg.). Songklanakarin J. Sci. Technol. 25(3): 327-340.
Pliura A., Yu Q., Zhang S. Y., Mackay J., Pierre P. and Bousquet J. (2005). Variation in wood density and shrinkage and their relationship to growth young poplar hybrids crosses. Forest Sci J, 51: 472-482

Wikipedia (2008). Coconut. <http://www.w3.org/TR/xhtml> accessed on $27^{\text {th }}$ January, 2008.

Received: 25 September 2014; Revised: 01 February 2014 Accepted: 22 December 2014. 